\title{
Time in range centered diabetes care
}

\author{
Klemen Dovc ${ }^{1,2}$ and Tadej Battelino ${ }^{1,2}$ \\ ${ }^{1}$ University Children's Hospital, University Medical Center Ljubljana, Ljubljana, Slovenia \\ ${ }^{2}$ Faculty of Medicine, University of Ljubljana, Ljubljana, Slovenia
}

\begin{abstract}
Optimal glycemic control remains challenging and elusive for many people with diabetes. With the comprehensive clinical evidence on safety and efficiency in large populations, and with broader reimbursement, the adoption of continuous glucose monitoring (CGM) is rapidly increasing. Standardized visual reporting and interpretation of CGM data and clear and understandable clinical targets will help professionals and individuals with diabetes use diabetes technology more efficiently, and finally improve long-term outcomes with less everyday disease burden. For the majority of people with type 1 or type 2 diabetes, time in range (between 70 and $180 \mathrm{mg} / \mathrm{dL}$, or 3.9 and $10 \mathrm{mmol} / \mathrm{L}$ ) target of more than $70 \%$ is recommended, with each incremental increase of $5 \%$ towards this target being clinically meaningful. At the same time, the goal is to minimize glycemic excursions: a recommended target for a time below range $(<70 \mathrm{mg} / \mathrm{dL}$ or $<3.9 \mathrm{mmol} / \mathrm{L})$ is less than $4 \%$, and time above range $(>180 \mathrm{mg} / \mathrm{dL}$ or $10 \mathrm{mmol} / \mathrm{L})$ less than $25 \%$, with less stringent goals for older individuals or those at increased risk. These targets should be individualized: the personal use of CGM with the standardized data presentation provides all necessary means to accurately tailor diabetes management to the needs of each individual with diabetes.
\end{abstract}

Key words: time in range, glucose variability, continuous glucose monitoring, diabetes technology, closed-loop, self-monitoring of blood glucose, diabetes mellitus

\section{Introduction}

Diabetes has an increasing worldwide prevalence over the past decades from 151 million in 2000 to estimated 463 million (9.3\% of all adults aged 20-79 yr) in 2020, and an additional 1.1 million children and adolescents with type 1 diabetes (1). Living with diabetes is challenging for individuals with this chronic condition as well as for those taking care of them. The lifelong goal of diabetes care is maintaining glucose levels as close to normal as possible and as early as possible in the course of the disease, thus delaying or possibly preventing devastating long-term diabetes complications (2-5).

Optimal diabetes management should be multidisciplinary and tailored for each person with diabetes (PWD), and is dependent on regular glucose monitoring, precise insulin dosing, and rational decisionmaking support. However, everyday diabetes care is complicated by the variability in insulin requirements for each PWD as insulin dose needed to maintain normoglycemia fluctuates from one day (or night) to another, and might be, especially in children and adolescents, challenging to achieve with conventional treatment modalities $(6,7)$.

In the past decades, glucose management was primarily assessed with the glycated hemoglobin A1c (HbA1c), an evidence-based and broadly-accepted surrogate outcome measure for evaluating the efficacy of diabetes care in routine clinical practice and in numerous clinical trials (including Diabetes Control and Complications Trial (DCCT) and the Epidemiology of Diabetes Interventions and Complications (EDIC) followup study of the DCCT cohort), and was recognized as a reliable and indirect biomarker that reflects long-term average glucose control $(2-5,8)$. Current international guidelines recommend that $\mathrm{HbA} 1 \mathrm{c}$ for the majority of children and nonpregnant adults should be below 53 $\mathrm{mmol} / \mathrm{mol}(7 \%)$ or even below $47.5 \mathrm{mmol} / \mathrm{mol}(6.5 \%)$ if this can be achieved safely $(9,10)$.

While $\mathrm{HbA1c}$ realistically captures the average glycemic control in the retrospect, it is limited in assessing short-term outcomes and day-to-day glucose fluctuations $(11,12)$. There is substantial evidence that these glucose excursions »beyond HbA1c« are

Received: September 15, 2020 Accepted: September 17, 2020

Corresponding author: Tadej Battelino, M.D., Ph.D., Department of Pediatric Endocrinology, Diabetes and Metabolic Diseases, University Children's Hospital, Bohoriceva 20, SI-1000 Ljubljana, Slovenia

E-mail: tadej.battelino@mf.uni-lj.si

ORCID: 0000-0002-0273-4732

This is an open-access article distributed under the terms of the Creative Commons Attribution NonCommercial No Derivatives (by-nc-nd) License <http://creativecommons.org/licenses/by-nc-nd/4.0/>. 
associated with the damage to susceptible organs or/and chromosomes, likely through oxidative stress (13-15), and were highlighted as significant risk factors for cognitive function and evolving brain structures early in the disease course, especially in young children with type 1 diabetes (16-18). Additionally, HbA1c lacks the information about acute complications, such as severe hypoglycemia or diabetic ketoacidosis that are, together with the fear of hypoglycemia, important barriers towards diabetes care optimization. Moreover, acute complications cause stress and anxiety, increase treatment costs, and decrease the quality of life (QoL) and psychological well-being of the youth with diabetes and their families $(12,19,20)$.

Continuous glucose monitoring (CGM), either real-time (rtCGM) or intermittently scanned (isCGM), effectively addresses these barriers: data derived from CGM present a more comprehensive glucose control picture than HbA1c alone (21). CGM devices provide a broad spectrum of additional glucose management metrics, including proportions of time in range (TIR), time below range (TBR), time above range (TAR), and glucose variability $(\mathrm{GV})$, that are at hand to PWDs and their health-care providers (HCPs) for individualizing the diabetes management and for making real-time treatment modifications.

\section{From Intermittent to Continuous Glucose} Monitoring

Regular glucose monitoring allows PWDs to guide their insulin therapy and assess whether their glucose targets are safely achieved. Frequent self-monitoring of blood glucose (SMBG) from capillary blood has considerably improved glycemic control by giving users the capacity to self-manage and individually tailor insulin dosing, and is considered a fundamental component of effective diabetes treatment and daily management of PWDs on insulin therapy (22).

SMBG has several limitations as blood is sampled intermittently, pinpointing only fragments of real glucose fluctuations, thus failing to reveal ongoing glucose excursions even if performed frequently. Episodes of asymptomatic hypoglycemia and also hyperglycemia could therefore be overlooked and not incorporated into decision-making. Additionally, a recent study demonstrated that many glucometers for personal use previously cleared by authorities in real life do not meet the level of accuracy currently required for regulatory clearance (23).

SMBG is throughout the world being replaced with CGM as the glucose monitoring of choice for insulin dosing; this replacement is based on a considerable body of evidence generated over the past 15 years. Contrary to SMBG, CGM provides an almost continuous string of glucose concentration measurements (every 1-5 min). CGM devices generally consist of a disposable on-body sensor that measures glucose concentration in the interstitial fluid, and a transmitter that broadcasts the sensor values (usually in 5-15 min intervals) to a dedicated receiver and/or other portable devices (e.g. smartphone, smart-watch, tablet). Data can be seen in real-time (rtCGM), stored in the cloud and shared with other family members. The CGM sensor values usually closely correlate with blood glucose concentration when glucose is stable, with a mean time lag of $5 \mathrm{~min}$ or less; during episodes of rapid glucose changes like post-simple-carbohydrate meal or exercise, however, the time lag can exceed 10 minutes (24). isCGM is a variety of CGM that presents glucose concentration only on demand $(25,26)$ but with recently enabled alarms it is coming closer to rtCGMs.

The only currently approved implantable CGM system has a sensor that is fully implanted under the skin by a healthcare provider, and functions for 90-180 days with data visualization through an on-body device (27).

Following the first major randomized controlled trial (RCT) with CGM use funded by JDRF (28), numerous RCTs confirmed efficacy and safety of CGM devices in both people affected with type 1 and type 2 diabetes (29-35), including individuals with severe hypoglycemia and/or hypoglycemia unawareness (36-39), on multiple daily injections (MDI) therapy (40), and particularly during pregnancy complicated by type 1 diabetes (41). Importantly, these positive outcomes were associated with a projected yearly reduction in diabetes-related cost worth several million USD (42). Additionally, user satisfaction and consequently mean sensor usage was significantly higher, including significant improvement of QoL measures (43).

The use of CGMs has been endorsed by the American Diabetes Association (ADA) in its 2020 Standards of Medical Care in Diabetes (33) the American Association of Clinical Endocrinologists (AACE) $(44,45)$, the International Society for Pediatric and Adolescent Diabetes (ISPAD) (46), and the Endocrine Society (47). The use of CGM is globally increasing exponentially in all age groups. Recent data from the T1D Exchange Registry reported that about $30 \%$ of participants have been using CGM in the period from 2016 to 2018 compared to $7 \%$ in 2010 to 2012 (48). Similarly, the most recent DPV Registry reported extensive CGM use in the majority of children with type 1 diabetes aged below $10 \mathrm{yr}$ and overall usage in $38 \%$ of individuals with type 1 diabetes (49). This significant increase is likely related to the approval of isCGM and rtCGM systems for non-adjunctive use, better accuracy and reliability of CGM devices, as well as broader reimbursement policy, some with demonstrated cost-effectiveness $(50,51)$.

Real-world efficacy data are in line with observations from RTCs: in a European registry, the CGM use was associated with better mean glucose and less hypoglycemia (52), in the T1D Exchange Registry, CGM usage was associated with lower HbA1c (48), and similarly in the DPV Registry CGM initiation lowered $\mathrm{HbA1c}$ and reduced risk for both SH and DKA (53). Recently, in the largest real-world data set including 
more than 10.000 individuals with type 1 diabetes from the UK, isCGM use improved glycemic control, especially in those with a higher baseline $\mathrm{HbA1c}$, improved hypoglycemic awareness, reduced diabetesrelated distress, and reduced hospital admissions (54). A recent had-to-had comparison between rtCGM and isCGM demonstrated potential advantages of the former, which may influence further development of CGM devices (55).

\section{Standardized Data Reporting Interpretation}

CGM data can be accessed in real-time on personal devices and curated personal data can be viewed using software packages. The data analysis tools offer PWDs and HCPs a wide range of metrics of glucose control quality, including proportion of sensor use, mean glucose, glucose management indicator (GMI; previously "estimated HbA1c"), glycemic variability (coefficient of variation - CV) and time in ranges - TIR, TBR and TAR $(21,56)$. Some of these metrics are useful research tools and others have been welcomed by patient-groups for providing insights into the quality of glucose control. However, until recently, these metrics were reported in various ways and ranges were defined diversely, therefore, it was almost impossible to compare results from one report to another.

In 2017, an international consensus recommended standardized CGM reporting and defined outcomes definitions with a core set of ten CGM metrics for reports (21). Definitions of the minimum requirements for CGM performance, such as meeting ISO (International Organization for Standardization) standards, the relationship of dependence of CGM calibration with glucometers (non-adjunctive us), and an acceptable CGM accuracy, defined as an absolute relative difference (MARD), were agreed upon. For reliable data assessment, studies have demonstrated that 10-14 d of CGM data generally provide a good approximation of 3 months of glucose data (57).

It is imperative that all CGM users should be trained in how to access, interpret, and answer questions regarding their glycemic control with accessible devices and tools.

\section{Decision Making and Time in Range Targets}

To make CGM data clinically meaningful for routine day-to-day diabetes management, clear guidance on CGM-derived glycemic targets should be provided to both PWDs and HCPs.

Recently, several major international societies formally endorsed an international consensus report on clinical targets for CGM data (58); notably, the consensus participants included also individuals with diabetes outside the medical profession.

The consensus suggested easy to understand TIR targets, along with TBR and TAR targets for routine management of type 1 and type 2 diabetes (Table 1). The reporting, presentation and visualization of CGM data should smoothen the communication between PWDs and HCPs, particularly when a standardized report (eg. Ambulatory Glucose Profile - AGP (59)) displays the key CGM metrics, including proportions of glucose values in different ranges over a specified time period, the recommended target for each CGM data range, and a visual demonstration of the CGM values distribution according to the time of day.

The principal goal for all children and adults with type 1 diabetes and type 2 diabetes is to maintain:

- At least 70\% ((16 h and 48 min per d) of TIR (70-180 $\mathrm{mg} / \mathrm{dL} / 3.9-10 \mathrm{mmol} / \mathrm{L})$,

while at the same time minimizing both TBR and TAR:

- less than $4 \%(1 \mathrm{~h}$ per $\mathrm{d})$ of TBR $(<70 \mathrm{mg} / \mathrm{dL} / 3.9$ $\mathrm{mmol} / \mathrm{L})$ and

- less than $25 \%$ (6 h per d) of TAR (> $180 \mathrm{mg} / \mathrm{dL} / 10$ $\mathrm{mmol} / \mathrm{L})$.

Targets should be individualized and in line with personal needs and circumstances. Each incremental $5 \%$ improvement in TIR is associated with clinically significant benefit.

While for pregnancy complicated with diabetes recommended targets remain the same, TIR is defined tighter (63-140 mg/dL) as glucose levels are physiologically lower during pregnancy (60).

A relevant improvement in diabetes care with the use of the new metrics is only possible through its broad understanding and adoption by PWDs and HCPs. It is therefore important to demonstrate that TIR metrics relate to and predict clinical outcomes so that we can together finally improve long-term diabetes outcomes with less day-to-day disease burden.

Because TIR can be evaluated on a near-hourly basis, it provides an important advantage over HbA1c: interpreting glycemic control in terms of TIR offers a more nuanced, cause-and-effect related understanding of glucose fluctuations. One can recognize behaviours and decisions that drive glucose levels out-of-range and prospectively find where/when changes can be made. From PWDs perspective, TIR is more accessible and at the same time more intuitive. For example, in one survey of 3461 PWDs, TIR emerged as the top outcome measure considered to have a 'big impact' on daily life with diabetes that both reflects PWDs' priorities and can be used to quantitatively evaluate treatment efficacy (12).

To show the correlation between HbA1c and TIR, Vigersky and McMahon analyzed data from 18 studies including 2577 PWD and found a strong relationship between TIR and HbA1c $(\mathrm{R}=-0.84$; R2 = 0.71) (60). Their results showed that for every $10 \%$ change in TIR, there was a $0.8 \%$ change in HbA1c.

Similar relationships were observed by Hirsch and colleagues who analyzed individual-level data from four randomized trials including 545 PWDs who had central laboratory measurements of $\mathrm{HbA} 1 \mathrm{c}$. TIR of $70 \%$ and $50 \%$ strongly corresponded with an $\mathrm{HbA} 1 \mathrm{c}$ of approximately $7 \%(53 \mathrm{mmol} / \mathrm{mol})$ and $8 \%(64 \mathrm{mmol} / \mathrm{mol})$, respectively. 
Table 1. Targets for glycemic control: Type 1 / Type 2 and older / high-risk individuals

\begin{tabular}{|c|c|c|c|}
\hline & & Type 1 / Type 2 & $\begin{array}{l}\text { Older/high-risk } \\
\text { Type } 1 \text { / Type } 2\end{array}$ \\
\hline \multirow[t]{4}{*}{ Time above range (TAR) } & Above target range & $\begin{array}{c}>180 \mathrm{mg} / \mathrm{dL} \\
>10.0 \mathrm{mmol} / \mathrm{L}\end{array}$ & \\
\hline & $\%$ of time/d & $\begin{array}{l}<25 \% \\
<6 \mathrm{~h}\end{array}$ & \\
\hline & Above target range & $\begin{array}{c}>250 \mathrm{mg} / \mathrm{dL} \\
>13.9 \mathrm{mmol} / \mathrm{L}\end{array}$ & $\begin{array}{c}>250 \mathrm{mg} / \mathrm{dL} \\
>13.9 \mathrm{mmol} / \mathrm{L}\end{array}$ \\
\hline & $\%$ of time/d & $\begin{array}{c}<5 \% \\
<1 \mathrm{~h}, 12 \min \end{array}$ & $\begin{array}{c}<10 \% \\
<2 \mathrm{~h}, 24 \mathrm{~min}\end{array}$ \\
\hline \multirow[t]{2}{*}{ Time in range (TIR) } & Target range & $\begin{array}{c}70-180 \mathrm{mg} / \mathrm{dL} \\
3.9-10.0 \mathrm{mmol} / \mathrm{L}\end{array}$ & $\begin{array}{c}70-180 \mathrm{mg} / \mathrm{dL} \\
3.9-10.0 \mathrm{mmol} / \mathrm{L}\end{array}$ \\
\hline & $\%$ of time/d & $\begin{array}{c}>70 \% \\
>16 \mathrm{~h}, 48 \mathrm{~min}\end{array}$ & $\begin{array}{l}>50 \% \\
>12 \mathrm{~h}\end{array}$ \\
\hline \multirow[t]{4}{*}{ Time below range (TBR) } & Below target range & $\begin{array}{c}<70 \mathrm{mg} / \mathrm{dL} \\
<3.9 \mathrm{mmol} / \mathrm{L}\end{array}$ & $\begin{array}{c}<70 \mathrm{mg} / \mathrm{dL} \\
<3.9 \mathrm{mmol} / \mathrm{L}\end{array}$ \\
\hline & $\%$ of time/d & $\begin{array}{l}<4 \% \\
<1 \mathrm{~h}\end{array}$ & $\begin{array}{c}<1 \% \\
<5 \mathrm{~min}\end{array}$ \\
\hline & Below target range & $\begin{array}{c}<54 \mathrm{mg} / \mathrm{dL} \\
<3.0 \mathrm{mmol} / \mathrm{L}\end{array}$ & \\
\hline & $\%$ of time/d & $\begin{aligned} & <1 \% \\
< & 15 \min \end{aligned}$ & \\
\hline
\end{tabular}

Each incremental 5\% increase towards time in range (TIR) targets is associated with clinically significant benefits for Type 1 / Type 2. Adapted from: Battelino T, et al. Clinical targets for continuous glucose monitoring data interpretation: recommendations from the International Consensus on Time in Range (58).

An increase in TIR of $10 \%$ (2.4 h per day) decreased $\mathrm{HbA} 1 \mathrm{c}$ for about $0.5 \%(5.0 \mathrm{mmol} / \mathrm{mol})(61)$. Petersson and coworkers analyzed data from 133 children with type 1 diabetes from Sweden and demonstrated a significant non-linear relationship between time in tighter range $70-140 \mathrm{mg} / \mathrm{dL}$ and HbA1c $\left(\mathrm{R}^{2}=0.69\right)$ over 60 days in frequent CGM (at $80 \%$ of the time) users (62). Beck and coworkers (63) re-analyzed data from the DCCT study. They used 7-point blood glucose profiles to validate the use of TIR as an outcome measure for clinical trials and demonstrated that the hazard ratio for retinopathy progression increased by $64 \%$ for each $10 \%$ decrease in TIR. Similarly, the hazard ratio for microalbuminuria development increased by $40 \%$ for each $10 \%$ reduction in TIR. Lu and colleagues evaluated the association between the TIR, assessed by CGM, diabetic retinopathy as a marker of microvascular complications (64), and intima media thickness, as a marker of macrovascular complications (65), in individuals with type 2 diabetes. Individuals with more progressive retinopathy, regardless of stage, and with abnormal intima media thickness had significantly lower TIR, and a decreased risk for complications with improved TIR was demonstrated (64, 65). Recently, an association between higher TIR and reduction in the urinary creatinine-albumin ration was demonstrated from a prospective randomized controlled trial (66). Several prospective clinical trials with TIR as the primary outcome are ongoing.

Finally, TIR can be used for evaluating the efficacy of different treatment modalities. Automated glucoseresponsive insulin therapy (closed-loop) was revitalized (67) and a roadmap towards closing-the-loop in six steps was defined 15 yr ago $(68,69)$. Consequently, a broad spectrum of treatment modalities for closing the loop is currently available on the market (in details discussed elsewhere (70)), including low-glucose suspend $(71,72)$, predictive low-glucose suspend systems MiniMed 640G (Medtronic Diabetes, USA) and Tandem t:slim X2 Insulin Pump with Basal IQ ${ }^{\circledR}$ Technology (Tandem Diabetes care, USA) $(73,74)$ and automated insulin delivery systems Medtronic MiniMed 670G and 780G (Medtronic Diabetes, USA) (75), DBLG1 (Diabeloop, France) (76), Tandem Diabetes Care t:slim X2 with Control IQ (Tandem Diabetes care, USA) (77) and CamAPX FX (CamDiab LtD, UK) (78).

The efficacy of newer technologies was evaluated in a recent network meta-analysis: closed-loop systems are demonstrated to have several advantages over other treatment modalities (79). Figure 1 summarizes data regarding TIR from recent randomized controlled trials including individuals with type 1 diabetes using either closed-loop therapy, predictive low glucose suspend or 


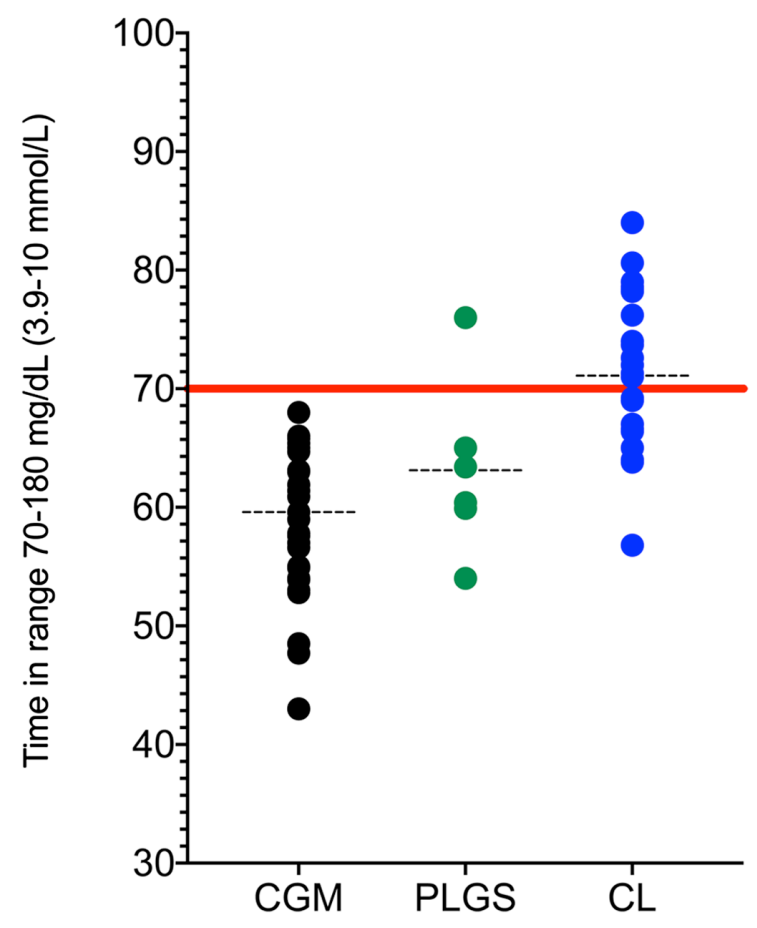

Fig. 1. Time in range for different treatment modalities from recent randomized controlled trials. CGM, Continuous Glucose Monitoring; PLGS, Predictive Low Glucose Suspend; CL, Closed-loop.Data from randomized controlled trials including children, adolescents and adults with type 1 diabetes for the last 5 years are included (34-36, 38, 39, 55, 73, 74, $77,78,80-116)$.

CGM alone.

\section{Summary}

In conclusion, with a proven benefit on glycemic outcomes and QoL, CGM devices are being increasingly adopted worldwide. To unify and improve clinical outcomes and quality of life with our routine diabetes care, we need to constantly improve the presentation and usage of provided CGM data. Individual CGM daily glucose profiles within the AGP can be used as a standardized overview and can effectively guide shared decision-making between a user and her/his HCP to personalize diabetes care and enable real-time treatment adjustments. This communication can be facilitated with clear and understandable time in ranges targets. Based on existing data, current recommendations set time in range $(70-180 \mathrm{mg} / \mathrm{dL}$, or $3.9-10 \mathrm{mmol} / \mathrm{L}$ ) of more than $70 \%$, with time below range $(<70 \mathrm{mg} / \mathrm{dL}$, or $<3.9 \mathrm{mmol} / \mathrm{L})$ of less than $4 \%$ for the majority of people with type 1 or type 2 diabetes. Every 5\% increment towards the time in range target is clinically meaningful. All treatment targets can be effective in practice only if personalized and agreed upon with each individual with diabetes.

Conflict of Interests: KD served on advisory board of Novo Nordisk and has received speakers honoraria from Eli Lilly. TB has received honoraria for participation on advisory boards for Novo Nordisk, Sanofi, Eli Lilly and Company, Boehringer, Medtronic, and Indigo, and as a speaker for AstraZeneca, Eli Lilly and Company, Novo Nordisk, Medtronic, Sanofi, and Roche. TB owns stocks of DreaMed Diabetes. TB's institution has received research grant support from Abbott Diabetes Care, Medtronic, Novo Nordisk, GluSense, Sanofi, Sandoz, and Diamyd. The study was funded in part by the University Medical Centre Ljubljana Research and Development Grant no. 20110359. TB received grants from the National Institutes of Health - NIDDK, and from the European Commission. KD and TB were funded in part by the Slovenian National Research Agency Grants no. J3-6798, V3-1505 and P3-0343.

\section{References}

1. International Diabetes Federation. Worldwide toll of diabetes [Internet]. IDF Diabetes Atlas, 9th Edition. 2019 [cited 2020 Jul 27]. Available from: https://diabetesatlas.org/en/sections/worldwide-toll-of-diabetes.html.

2. Diabetes Control and Complications Trial Research Group. Effect of intensive diabetes treatment on the development and progression of long-term complications in adolescents with insulin-dependent diabetes mellitus: Diabetes Control and Complications Trial. J Pediatr 1994;125: 177-88. [Medline] [CrossRef]

3. Lind M, Svensson AM, Kosiborod M, Gudbjörnsdottir S, Pivodic A, Wedel H, et al. Glycemic control and excess mortality in type 1 diabetes. N Engl J Med 2014;371: 1972-82. [Medline] [CrossRef]

4. Schade DS, Lorenzi GM, Braffett BH, Gao X, Bainbridge KE, Barnie A, et al. DCCT/EDIC Research Group. Hearing impairment and type 1 diabetes in the diabetes control and complications trial/ epidemiology of diabetes interventions and complications (DCCT/EDIC) cohort. Diabetes Care 2018;41: 2495-501. [Medline] [CrossRef]

5. Atkinson MA, Eisenbarth GS, Michels AW. Type 1 diabetes. Lancet 2014;383: 69-82. [Medline] [CrossRef]

6. Dovc K, Boughton C, Tauschmann M, Thabit H, Bally L, Allen JM, et al. APCam11, AP@Home, and KidsAP Consortia. Young children have higher variability of insulin requirements: Observations during hybrid closed-loop insulin delivery. Diabetes Care 2019;42: 1344-7. [Medline] [CrossRef]

7. Ruan Y, Thabit H, Leelarathna L, Hartnell S, Willinska ME, Dellweg S, et al.AP@home Consortium. Variability of insulin requirements over 12 weeks of closed-loop insulin delivery in adults with type 1 diabetes. Diabetes Care 2016;39: 830-2. [Medline] [CrossRef]

8. Yau JWY, Rogers SL, Kawasaki R, Lamoureux EL, Kowalski JW, Bek T, et al. Meta-Analysis for Eye Disease (META- 
EYE) Study Group. Global prevalence and major risk factors of diabetic retinopathy. Diabetes Care 2012;35: 556-64. [Medline] [CrossRef]

9. American Diabetes Association. Glycemic targets: Standards of medical care in diabetes-2020. Diabetes Care 2020;43(Suppl 1): S66-76. [Medline] [CrossRef]

10. Dimeglio LA, Acerini CL, Codner E, Craig ME, Hofer SE, Pillay K, et al. Glycemic control targets and glucose monitoring for children, adolescents, and young adults with diabetes 2018 ISPAD Clinical Practice Consensus Guidelines. 2018;(July):105-14.

11. Beyond A1C Writing Group. Need for regulatory change to incorporate beyond A1C glycemic metrics. Diabetes Care 2018;41: e92-4. [Medline] [CrossRef]

12. Runge AS, Kennedy L, Brown AS, Dove AE, Levine BJ, Koontz SP, et al. Does time-in-range matter? Perspectives from people with diabetes on the success of current therapies and the drivers of improved outcomes. Clin Diabetes 2018;36: 112-9. [Medline] [CrossRef]

13. Lachin JM, Bebu I, Bergenstal RM, Pop-Busui R, Service FJ, Zinman B, et al. DCCT/EDIC Research Group. Association of glycemic variability in type 1 diabetes with progression of microvascular outcomes in the diabetes control and complications trial. Diabetes Care 2017;40: 777-83. [Medline] [CrossRef]

14. Lovshin JA, Bjornstad P, Lovblom LE, Bai JW, Lytvyn Y, Boulet G, et al. Atherosclerosis and microvascular complications: results from the Canadian study of longevity in type 1 diabetes. Diabetes Care 2018;41: 2570-8. [Medline] [CrossRef]

15. Tesovnik T, Kovac J, Hovnik T, Dovc K, Bratina N, Battelino T, et al. Association of glycemic control and cell stress with telomere attrition in type 1 diabetes. JAMA Pediatr 2018;172: 879-81. [Medline] [CrossRef]

16. Foland-Ross LC, Reiss AL, Mazaika PK, Mauras N, Weinzimer SA, Aye T, et al. Diabetes Research in Children Network (DirecNet). Longitudinal assessment of hippocampus structure in children with type 1 diabetes. Pediatr Diabetes 2018;19: 1116-23. [Medline] [CrossRef]

17. Fox LA, Hershey T, Mauras N, Arbeláez AM, Tamborlane WV, Buckingham B, et al. Diabetes Research in Children Network (DirecNet). Persistence of abnormalities in white matter in children with type 1 diabetes. Diabetologia 2018;61: 1538-47. [Medline] [CrossRef]

18. Šuput Omladič J, Slana Ozimič A, Vovk A, Šuput D, Repovš G, Dovc K, et al. Acute hyperglycemia and spatial working memory in adolescents with type 1 diabetes. Diabetes Care 2020;43: 1941-4. [Medline] [CrossRef]

19. Van Name MA, Hilliard ME, Boyle CT, Miller KM, DeSalvo DJ, Anderson BJ, et al. Nighttime is the worst time: Parental fear of hypoglycemia in young children with type 1 diabetes. Pediatr Diabetes 2018;19: 114-20. [Medline] [CrossRef]

20. Frier BM. Hypoglycaemia in diabetes mellitus: epidemiology and clinical implications. Nat Rev Endocrinol 2014;10: 711-22. [Medline] [CrossRef]

21. Danne T, Nimri R, Battelino T, Bergenstal RM, Close KL, DeVries JH, et al. International consensus on use of continuous glucose monitoring. Diabetes Care 2017;40: 1631-40. [Medline] [CrossRef]

22. Nathan DM, Genuth S, Lachin J, Cleary P, Crofford O, Davis M, et al. Diabetes Control and Complications Trial Research Group. The effect of intensive treatment of diabetes on the development and progression of long-term complications in insulin-dependent diabetes mellitus. N Engl J Med 1993;329: 977-86. [Medline] [CrossRef]

23. Klonoff DC, Parkes JL, Kovatchev BP, Kerr D, Bevier WC, Brazg RL, et al. Investigation of the accuracy of 18 marketed blood glucose monitors. Diabetes Care 2018;41: 1681-8. [Medline] [CrossRef]

24. Zaharieva DP, Turksoy K, McGaugh SM, Pooni R, Vienneau T, Ly T, et al. Lag time remains with newer real-time continuous glucose monitoring technology during aerobic exercise in adults living with type 1 diabetes. Diabetes Technol Ther 2019;21: 313-21. [Medline] [CrossRef]

25. Langendam M, LuijfYM, Hooft L, DeVries JH, Mudde AH, Scholten RJ. Continuous glucose monitoring systems for type 1 diabetes mellitus. In: Langendam M, editor. Cochrane Database of Systematic Reviews. Chichester, UK: John Wiley \& Sons, Ltd; 2012. p. CD008101.

26. Piona C, Dovc K, Mutlu GY, Grad K, Gregorc P, Battelino T, et al. Non-adjunctive flash glucose monitoring system use during summer-camp in children with type 1 diabetes: The free-summer study. Pediatr Diabetes 2018;19: 1285-93. [Medline] [CrossRef]

27. Deiss D, Irace C, Carlson G, Tweden KS, Kaufman FR. Real-world safety of an implantable continuous glucose sensor over multiple cycles of use: a post-market registry study. Diabetes Technol Ther 2020;22: 48-52. [Medline] [CrossRef]

28. The Juvenile Diabetes Research Foundation Continuous Glucose Monitoring Study Group*, Group TJDRFCGMS, Tamborlane WV, Beck RW, Bode BW, Buckingham B, et al. Continuous glucose monitoring and intensive treatment of type 1 diabetes. N Engl J Med 2008;359(14): 1464-76.

29. DeSalvo DJ, Miller KM, Hermann JM, Maahs DM, Hofer SE, Clements MA, et al. T1D Exchange and DPV Registries. Continuous glucose monitoring and glycemic control among youth with type 1 diabetes: International comparison from the T1D exchange and DPV initiative. Pediatr Diabetes 2018;19: 1271-5. [Medline] [CrossRef]

30. Dovc K, Cargnelutti K, Sturm A, Selb J, Bratina N, Battelino T. Continuous glucose monitoring use and glucose variability in pre-school children with type 1 diabetes. Diabetes Res Clin Pract 2019;147: 76-80. [Medline]

31. Bergenstal RM. Continuous glucose monitoring: transforming diabetes management step by step. Vol. 391, The Lancet. Elsevier; 2018. p. 1334-6.

32. Kropff J, Choudhary P, Neupane S, Barnard K, Bain SC, Kapitza C, et al. Accuracy and longevity of an implantable continuous glucose sensor in the PRECISE study: A 180-day, prospective, multicenter, pivotal trial. Diabetes Care 2017;40: 63-8. [Medline] [CrossRef]

33. Maiorino MI, Signoriello S, Maio A, Chiodini P, Bellastella G, Scappaticcio L, et al. Effects of continuous glucose monitoring on metrics of glycemic control in diabetes: A Systematic Review with Meta-analysis of Randomized Controlled Trials. 
Diabetes Care 2020;43: 1146-56. [Medline] [CrossRef]

34. Thabit H, Prabhu JN, Mubita W, Fullwood C, Azmi S, Urwin A, et al. Use of factory-calibrated real-time continuous glucose monitoring improves time in target and $\mathrm{HbA}_{1 \mathrm{c}}$ in a multiethnic cohort of adolescents and young adults with type 1 diabetes: The millennials study. Diabetes Care 2020;43: 2537-43. [Medline] [CrossRef]

35. Laffel LM, Kanapka LG, Beck RW, Bergamo K, Clements MA, Criego A, et al. CGM Intervention in Teens and Young Adults with T1D (CITY) Study Group CDE10. Effect of continuous glucose monitoring on glycemic control in adolescents and young adults with type 1 diabetes: a randomized clinical trial. JAMA 2020;323: 2388-96. [Medline] [CrossRef]

36. van Beers CAJ, DeVries JH, Kleijer SJ, Smits MM, Geelhoed-Duijvestijn PH, Kramer MHH, et al. Continuous glucose monitoring for patients with type 1 diabetes and impaired awareness of hypoglycaemia (IN CONTROL): a randomised, open-label, crossover trial. Lancet Diabetes Endocrinol 2016;4: 893-902. [Medline] [CrossRef]

37. Little SA, Speight J, Leelarathna L, Walkinshaw E, Tan HK, Bowes A, et al. Sustained reduction in severe hypoglycemia in adults with type 1 diabetes complicated by impaired awareness of hypoglycemia: Two-year follow-up in the HypoCOMPaSS randomized clinical Trial. Diabetes Care 2018;41: 1600-7. [Medline]

38. Heinemann L, Freckmann G, Ehrmann D, Faber-Heinemann G, Guerra S, Waldenmaier D, et al. Real-time continuous glucose monitoring in adults with type 1 diabetes and impaired hypoglycaemia awareness or severe hypoglycaemia treated with multiple daily insulin injections (HypoDE): a multicentre, randomised controlled trial. Lancet 2018;391: 1367-77. [Medline] [CrossRef]

39. Bosi E, Choudhary P, de Valk HW, Lablanche S, Castañeda J, de Portu S, et al. SMILE Study Group. Efficacy and safety of suspend-before-low insulin pump technology in hypoglycaemia-prone adults with type 1 diabetes (SMILE): an open-label randomised controlled trial. Lancet Diabetes Endocrinol 2019;7: 462-72. [Medline] [CrossRef]

40. Oliver N, Gimenez M, Calhoun P, Cohen N, Moscardo V, Hermanns N, et al. Continuous glucose monitoring in people with type 1 diabetes on multiple-dose injection therapy: The relationship between Glycemic control and Hypoglycemia. Diabetes Care 2020;43: 53-8. [Medline] [CrossRef]

41. Murphy HR. Continuous glucose monitoring targets in type 1 diabetes pregnancy: every $5 \%$ time in range matters. Diabetologia 2019;62: 1123-8. [Medline] [CrossRef]

42. Murphy HR, Feig DS, Sanchez JJ, de Portu S, Sale A, De Portu S, CONCEPTT Collaborative Group. Modelling potential cost savings from use of real-time continuous glucose monitoring in pregnant women with Type 1 diabetes. Diabet Med 2019;36: 1652-8. [Medline] [CrossRef]

43. Polonsky WH, Hessler D, Ruedy KJ, Beck RW, DIAMOND Study Group. The impact of continuous glucose monitoring on markers of quality of life in adults with type 1 diabetes: Further findings from the DIAMOND randomized clinical trial. Diabetes Care 2017;40: 736-41. [Medline] [CrossRef]

44. Grunberger G, Handelsman Y, Bloomgarden ZT, Fonseca VA, Garber AJ, Haas RA, et al. American Association of Clinical Endocrinologists and American College of Endocrinology 2018 position statement on integration of insulin pumps and continuous glucose monitoring in patients with diabetes mellitus. Endocr Pract 2018;24: 302-8. [Medline] [CrossRef]

45. Garber AJ, Abrahamson MJ, Barzilay JI, Blonde L, Bloomgarden ZT, Bush MA, et al. Consensus statement by the American association of clinical endocrinologists and American college of endocrinology on the comprehensive type 2 diabetes management algorithm - 2019 executive summary. Vol. 25, Endocrine Practice. American Association of Clinical Endocrinologists; 2019. p. 69-100.

46. Sherr JL, Tauschmann M, Battelino T, de Bock M, Forlenza G, Roman R, et al. ISPAD Clinical Practice Consensus Guidelines 2018: diabetes technologies. Pediatr Diabetes 2018;19(Suppl 27): 302-25. [Medline] [CrossRef]

47. Peters AL, Ahmann AJ, Battelino T, Evert A, Hirsch IB, Murad MH, et al. Diabetes technology-continuous subcutaneous insulin infusion therapy and continuous glucose monitoring in adults: an Endocrine Society Clinical Practice Guideline. J Clin Endocrinol Metab 2016;101: 3922-37. [Medline] [CrossRef]

48. Foster NC, Beck RW, Miller KM, Clements MA, Rickels MR, DiMeglio LA, et al. State of type 1 diabetes management and outcomes from the T1D exchange in 2016-2018. Diabetes Technol Ther 2019;21: 66-72. [Medline] [CrossRef]

49. van den Boom L, Karges B, Auzanneau M, Rami-Merhar B, Lilienthal E, von Sengbusch S, et al. Temporal trends and contemporary use of insulin pump therapy and glucose monitoring among children, adolescents, and adults with type 1 diabetes between 1995 and 2017. Diabetes Care 2019;42: 2050-6. [Medline] [CrossRef]

50. Charleer S, Mathieu C, Nobels F, De Block C, Radermecker RP, Hermans MP, et al. RESCUE Trial Investigators. Effect of continuous glucose monitoring on glycemic control, acute admissions, and quality of life: A real-world study. J Clin Endocrinol Metab 2018;103: 1224-32. [Medline] [CrossRef]

51. Wan W, Skandari MR, Minc A, Nathan AG, Winn A, Zarei P, et al. Cost-effectiveness of continuous glucose monitoring for adults with type 1 diabetes compared with self-monitoring of blood glucose: The DIAMOND randomized trial. Diabetes Care 2018;41: 1227-34. [Medline] [CrossRef]

52. Battelino T, Liabat S, Veeze HJ, Castañeda J, Arrieta A, Cohen O. Routine use of continuous glucose monitoring in 10501 people with diabetes mellitus. Diabet Med 2015;32: 1568-74. [Medline] [CrossRef]

53. Tauschmann M, Hermann JM, Freiberg C, Papsch M, Thon A, Heidtmann B, et al. DPV Initiative. Reduction in diabetic ketoacidosis and severe hypoglycemia in pediatric type 1 diabetes during the first year of continuous glucose monitoring: A multicenter analysis of 3,553 subjects from the DPV registry. Diabetes Care 2020;43: e40-2. [Medline] [CrossRef]

54. Deshmukh H, Wilmot EG, Gregory R, Barnes D, Narendran P, Saunders S, et al. Effect of flash glucose monitoring on glycemic control, hypoglycemia, diabetes-related distress, and resource utilization in the association of british clinical diabetologists (Abcd) nationwide audit. Diabetes Care 2020;43: 2153-60. [Medline] [CrossRef]

55. Hásková A, Radovnická L, Petruželková L, Parkin CG, Grunberger G, Horová E, et al. Real-time CGM Is Superior to Flash Glucose Monitoring for Glucose Control in Type 1 Diabetes: The CORRIDA Randomized Control Trial. Diabetes 
Care 2020; dc200112. [Medline] [CrossRef]

56. Bergenstal RM, Beck RW, Close KL, Grunberger G, Sacks DB, Kowalski A, et al. Glucose management indicator (GMI): A new term for estimating A1C from continuous glucose monitoring. Diabetes Care 2018;41: 2275-80. [Medline] [CrossRef]

57. Riddlesworth TD, Beck RW, Gal RL, Connor CG, Bergenstal RM, Lee S, et al. Optimal sampling duration for continuous glucose monitoring to determine long-term glycemic control. Diabetes Technol Ther 2018;20:314-6. [Medline] [CrossRef]

58. Battelino T, Danne T, Bergenstal RM, Amiel SA, Beck R, Biester T, et al. Clinical targets for continuous glucose monitoring data interpretation: recommendations from the international consensus on time in range. Diabetes Care 2019;42: 1593-603. [Medline] [CrossRef]

59. Bergenstal RM, Ahmann AJ, Bailey T, Beck RW, Bissen J, Buckingham B, et al. Recommendations for standardizing glucose reporting and analysis to optimize clinical decision making in diabetes: the Ambulatory Glucose Profile (AGP). Diabetes Technol Ther 2013;15: 198-211. [Medline] [CrossRef]

60. Vigersky RA, McMahon C. The relationship of hemoglobin A1C to time-in-range in patients with diabetes. Diabetes Technol Ther 2019;21: 81-5. [Medline] [CrossRef]

61. Hirsch IB, Welsh JB, Calhoun P, Puhr S, Walker TC, Price DA. Associations between $\mathrm{HbA}_{1 \mathrm{c}}$ and continuous glucose monitoring-derived glycaemic variables. Diabet Med 2019;36: 1637-42. [Medline] [CrossRef]

62. Petersson J, Åkesson K, Sundberg F, Särnblad S. Translating glycated hemoglobin A1c into time spent in glucose target range: A multicenter study. Pediatr Diabetes 2019;20: 339-44. [Medline] [CrossRef]

63. Beck RW, Bergenstal RM, Riddlesworth TD, Kollman C, Li Z, Brown AS, et al. Validation of time in range as an outcome measure for diabetes clinical trials. Diabetes Care 2019;42: 400-5. [Medline] [CrossRef]

64. Lu J, Ma X, Zhou J, Zhang L, Mo Y, Ying L, et al. Association of time in range, as assessed by continuous glucose monitoring, with diabetic retinopathy in type 2 diabetes. Diabetes Care 2018;41: 2370-6. [Medline] [CrossRef]

65. Lu J, Ma X, Shen Y, Wu Q, Wang R, Zhang L, et al. Time in range is associated with carotid intima-media thickness in type 2 diabetes. Diabetes Technol Ther 2020;22: 72-8. [Medline] [CrossRef]

66. Ranjan A, Rosenlund S, Hansen TW, Rossing P, Andersen S, Norgaard K. 28-LB: improved time in glucose range over one year is associated with reduced albuminuria in sensor-augmented insulin pump-treated type 1 diabetes. Diabetes 2020;69(Supplement 1): 28 -LB. [CrossRef]

67. Battelino T, Phillip M. The first meeting of the Loop Club. J Pediatr Endocrinol Metab 2004;17: 375-6. [Medline] [CrossRef]

68. Kowalski A, Lum JW. Juvenile diabetes research foundation: artificial pancreas project. 2015;1224-6.

69. Kowalski AJ. Can we really close the loop and how soon? Accelerating the availability of an artificial pancreas: a roadmap to better diabetes outcomes. Diabetes Technol Ther 2009;11(Suppl 1): S113-9. [Medline] [CrossRef]

70. Dovc K, Battelino T. Evolution of diabetes technology. Endocrinol Metab Clin North Am 2020;49: 1-18. [Medline] [CrossRef]

71. Bergenstal RM, Tamborlane WV, Ahmann A, Buse JB, Dailey G, Davis SN, et al. STAR 3 Study Group. Effectiveness of sensor-augmented insulin-pump therapy in type 1 diabetes. N Engl J Med 2010;363: 311-20. [Medline] [CrossRef]

72. Ly TT, Nicholas JA, Retterath A, Lim EM, Davis EA, Jones TW. Effect of sensor-augmented insulin pump therapy and automated insulin suspension vs standard insulin pump therapy on hypoglycemia in patients with type 1 diabetes: a randomized clinical trial. JAMA 2013;310: 1240-7. [Medline] [CrossRef]

73. Forlenza GP, Li Z, Buckingham BA, Pinsker JE, Cengiz E, Wadwa RP, et al. Predictive low-glucose suspend reduces hypoglycemia in adults, adolescents, and children with type 1 diabetes in an at-home randomized crossover study: Results of the PROLOG trial. Diabetes Care 2018;41: 2155-61. [Medline] [CrossRef]

74. Battelino T, Nimri R, Dovc K, Phillip M, Bratina N. Prevention of hypoglycemia with predictive low glucose insulin suspension in children with type 1 diabetes: A randomized controlled trial. Diabetes Care 2017;40: 764-70. [Medline] [CrossRef]

75. Garg SK, Weinzimer SA, Tamborlane WV, Buckingham BA, Bode BW, Bailey TS, et al. Glucose outcomes with the in-home use of a hybrid closed-loop insulin delivery system in adolescents and adults with type 1 diabetes. Diabetes Technol Ther 2017;19: 155-63. [Medline] [CrossRef]

76. Benhamou PY, Franc S, Reznik Y, Thivolet C, Schaepelynck P, Renard E, et al. Closed-loop insulin delivery in adults with type 1 diabetes in real-life conditions: a 12-week multicentre, open-label randomised controlled crossover trial. Lancet Digit Heal. 2019;1: e17-25. [CrossRef]

77. Brown SA, Kovatchev BP, Raghinaru D, Lum JW, Buckingham BA, Kudva YC, et al. iDCL Trial Research Group. Six-month randomized, multicenter trial of closed-loop control in type 1 diabetes. N Engl J Med 2019;381: 1707-17. [Medline] [CrossRef]

78. Tauschmann M, Thabit H, Bally L, Allen JM, Hartnell S, Wilinska ME, et al. APCam11 Consortium. Closed-loop insulin delivery in suboptimally controlled type 1 diabetes: a multicentre, 12-week randomised trial. Lancet 2018;392: 1321-9. [Medline] [CrossRef]

79. Pease AJ, Zomer E, Liew D, Earnest A, Soldatos G, Ademi Z, et al. Cost-effectiveness analysis of a hybrid closed-loop system versus multiple daily injections and capillary glucose testing for adults with type 1 diabetes. Diabetes Technol Ther 2020; 1-36. [Medline]

80. Russell SJ, El-Khatib FH, Sinha M, Magyar KL, McKeon K, Goergen LG, et al. Outpatient glycemic control with a bionic pancreas in type 1 diabetes. N Engl J Med 2014;371:313-25. [Medline] [CrossRef]

81. de Bock MI, Roy A, Cooper MN, Dart JA, Berthold CL, Retterath AJ, et al. Feasibility of outpatient 24-Hour Closed-Loop insulin delivery. Diabetes Care 2015;38: e186-7. [Medline] [CrossRef]

82. Ly TT, Roy A, Grosman B, Shin J, Campbell A, Monirabbasi S, et al. Day and night closed-loop control using the integrated 
Medtronic hybrid closed-loop system in type 1 diabetes at diabetes camp. Diabetes Care 2015;38: 1205-11. [Medline] [CrossRef]

83. Thabit H, Tauschmann M, Allen JM, Leelarathna L, Hartnell S, Wilinska ME, et al. Home use of an artificial beta cell in type 1 diabetes. N Engl J Med 2015;373: 2129-40. [Medline] [CrossRef]

84. Del Favero S, Boscari F, Messori M, Rabbone I, Bonfanti R, Sabbion A, et al. Randomized summer camp crossover trial in 5-to 9-year-old children: Outpatient wearable artificial pancreas is feasible and safe. Diabetes Care 2016;39: 1180-5. [Medline] [CrossRef]

85. Ly TT, Buckingham BA, DeSalvo DJ, Shanmugham S, Satin-Smith M, DeBoer MD, et al. Day-and-night closed-loop control using the unified safety system in adolescents with type 1 diabetes at camp. Diabetes Care 2016;39: e106-7. [Medline] [CrossRef]

86. Russell SJ, Hillard MA, Balliro C, Magyar KL, Selagamsetty R, Sinha M, et al. Day and night glycaemic control with a bionic pancreas versus conventional insulin pump therapy in preadolescent children with type 1 diabetes: a randomised crossover trial. Lancet Diabetes Endocrinol 2016;4: 233-43. [Medline] [CrossRef]

87. Tauschmann M, Allen JM, Wilinska ME, Thabit H, Acerini CL, Dunger DB, et al. Home use of day-and-night hybrid closed-loop insulin delivery in suboptimally controlled adolescents with type 1 diabetes: A 3-week, free-living, randomized crossover trial. Diabetes Care 2016;39: 2019-25. [Medline] [CrossRef]

88. Tauschmann M, Allen JM, Wilinska ME, Thabit H, Stewart Z, Cheng P, et al. Day-and-night hybrid closed-loop insulin delivery in adolescents with type 1 diabetes: A free-living, randomized clinical trial. Diabetes Care 2016;39: 1168-74. [Medline] [CrossRef]

89. Bally L, Thabit H, Kojzar H, Mader JK, Qerimi-Hyseni J, Hartnell S, et al. Day-and-night glycaemic control with closedloop insulin delivery versus conventional insulin pump therapy in free-living adults with well controlled type 1 diabetes: an open-label, randomised, crossover study. Lancet Diabetes Endocrinol 2017;5: 261-70. [Medline] [CrossRef]

90. Breton MD, Cherñavvsky DR, Forlenza GP, DeBoer MD, Robic J, Wadwa RP, et al. Closed-loop control during intense prolonged outdoor exercise in adolescents with type 1 diabetes: The artificial pancreas ski study. Diabetes Care 2017;40: 1644-50. [Medline] [CrossRef]

91. El-Khatib FH, Balliro C, Hillard MA, Magyar KL, Ekhlaspour L, Sinha M, et al. Home use of a bihormonal bionic pancreas versus insulin pump therapy in adults with type 1 diabetes: a multicentre randomised crossover trial. Lancet 2017;389: 369-80. [Medline] [CrossRef]

92. Biester T, Nir J, Remus K, Farfel A, Muller I, Biester S, et al. DREAM5: An open-label, randomized, cross-over study to evaluate the safety and efficacy of day and night closed-loop control by comparing the MD-Logic automated insulin delivery system to sensor augmented pump therapy in patients with type 1 diabetes at home. Diabetes Obes Metab 2019;21: 822-8. [Medline] [CrossRef]

93. Anderson SM, Buckingham BA, Breton MD, Robic JL, Barnett CL, Wakeman CA, et al. Hybrid closed-loop control is safe and effective for people with type 1 diabetes who are at moderate to high risk for hypoglycemia. Diabetes Technol Ther 2019;21: 356-63. [Medline] [CrossRef]

94. Ekhlaspour L, Forlenza GP, Chernavvsky D, Maahs DM, Wadwa RP, Deboer MD, et al. Closed loop control in adolescents and children during winter sports: Use of the Tandem Control-IQ AP system. Pediatr Diabetes 2019;20: 759-68. [Medline]

95. Forlenza GP, Ekhlaspour L, Breton M, Maahs DM, Wadwa RP, DeBoer M, et al. Successful at-home use of the tandem control-iq artificial pancreas system in young children during a randomized controlled trial. Diabetes Technol Ther 2019;21: 159-69. [Medline] [CrossRef]

96. Renard E, Tubiana-Rufi N, Bonnemaison-Gilbert E, Coutant R, Dalla-Vale F, Farret A, et al. Closed-loop driven by control-to-range algorithm outperforms threshold-low-glucose-suspend insulin delivery on glucose control albeit not on nocturnal hypoglycaemia in prepubertal patients with type 1 diabetes in a supervised hotel setting. Diabetes Obes Metab 2019;21: 183-7. [Medline] [CrossRef]

97. Tauschmann M, Allen JM, Nagl K, Fritsch M, Yong J, Metcalfe E, et al. KidsAP Consortium. Home use of day-and-night hybrid closed-loop insulin delivery in very young children: A multicenter, 3-week, randomized trial. Diabetes Care 2019;42: 594-600. [Medline] [CrossRef]

98. Breton MD, Kanapka LG, Beck RW, Ekhlaspour L, Forlenza GP, Cengiz E, et al. iDCL Trial Research Group. A randomized trial of closed-loop control in children with type 1 diabetes. N Engl J Med 2020;383: 836-45. [Medline] [CrossRef]

99. Brown SA, Beck RW, Raghinaru D, Buckingham BA, Laffel LM, Wadwa RP, et al. iDCL Trial Research Group. Glycemic outcomes of use of CLC versus PLGS in type 1 diabetes: a randomized controlled trial. Diabetes Care 2020;43: 1822-8. [Medline] [CrossRef]

100. Kovatchev B, Anderson SM, Raghinaru D, Kudva YC, Laffel LM, Levy C, et al. iDCL Study Group. Randomized controlled trial of mobile closed-loop control. Diabetes Care 2020;43: 607-15. [Medline] [CrossRef]

101. Haidar A, Tsoukas MA, Bernier-Twardy S, Yale JF, Rutkowski J, Bossy A, et al. A novel dual-hormone insulin-and-pramlintide artificial pancreas for type 1 diabetes: a randomized controlled crossover Trial. Diabetes Care 2020;43: 597-606. [Medline] [CrossRef]

102. Sherr JL, Buckingham BA, Forlenza GP, Galderisi A, Ekhlaspour L, Wadwa RP, et al. Safety and performance of the omnipod hybrid closed-loop system in adults, adolescents, and children with type 1 diabetes over 5 days under free-living conditions. Diabetes Technol Ther 2020;22: 174-84. [Medline] [CrossRef]

103. Wilson LM, Jacobs PG, Ramsey KL, Resalat N, Reddy R, Branigan D, et al. Dual-Hormone closed-loop system using a liquid stable glucagon formulation versus insulin-only closed-loop system compared with a predictive low glucose suspend system: an open-label, outpatient, single-center, crossover, randomized controlled trial. Diabetes Care 2020; dc192267. [Medline] [CrossRef] 
104. Buckingham BA, Raghinaru D, Cameron F, Bequette BW, Chase HP, Maahs DM, et al. In Home Closed Loop Study Group. Predictive low-glucose insulin suspension reduces duration of nocturnal hypoglycemia in children without increasing ketosis. Diabetes Care 2015;38: 1197-204. [Medline] [CrossRef]

105. Bolinder J, Antuna R, Geelhoed-Duijvestijn P, Kröger J, Weitgasser R, Kröger J, et al. Novel glucose-sensing technology and hypoglycaemia in type 1 diabetes: a multicentre, non-masked, randomised controlled trial. Lancet 2016;388: 2254-63. [Medline] [CrossRef]

106. Aleppo G, Ruedy KJ, Riddlesworth TD, Kruger DF, Peters AL, Hirsch I, et al. REPLACE-BG Study Group. REPLACEBG: A randomized trial comparing continuous glucose monitoring with and without routine blood glucose monitoring in adults with well-controlled type 1 diabetes. Diabetes Care 2017;40: 538-45. [Medline] [CrossRef]

107. Beck RW, Riddlesworth T, Ruedy K, Ahmann A, Bergenstal R, Haller S, et al. DIAMOND Study Group. Effect of continuous glucose monitoring on glycemic control in adults with type 1 diabetes using insulin injections the diamond randomized clinical trial. JAMA -. JAMA 2017;317: 371-8. [Medline] [CrossRef]

108. Lind M, Polonsky W, Hirsch IB, Heise T, Bolinder J, Dahlqvist S, et al. Continuous glucose monitoring vs conventional therapy for glycemic control in adults with type 1 diabetes treated with multiple daily insulin injections the gold randomized clinical trial. JAMA -. JAMA 2017;317: 379-87. [Medline] [CrossRef]

109. Oskarsson P, Antuna R, Geelhoed-Duijvestijn P, Kröger J, Weitgasser R, Bolinder J. Impact of flash glucose monitoring on hypoglycaemia in adults with type 1 diabetes managed with multiple daily injection therapy: a pre-specified subgroup analysis of the IMPACT randomised controlled trial. Diabetologia 2018;61: 539-50. [Medline] [CrossRef]

110. Abraham MB, Nicholas JA, Smith GJ, Fairchild JM, King BR, Ambler GR, et al. PLGM Study Group. Reduction in hypoglycemia with the predictive low-glucose management system: a long-term randomized controlled trial in adolescents with type 1 diabetes. Diabetes Care 2018;41: 303-10. [Medline]

111. Forlenza GP, Raghinaru D, Cameron F, Wayne Bequette B, Peter Chase H, Paul Wadwa R, et al. In-Home Closed-Loop (IHCL) Study Group. Predictive hyperglycemia and hypoglycemia minimization: In-home double-blind randomized controlled evaluation in children and young adolescents. Pediatr Diabetes 2018;19: 420-8. [Medline] [CrossRef]

112. Reddy M, Jugnee N, El Laboudi A, Spanudakis E, Anantharaja S, Oliver N. A randomized controlled pilot study of continuous glucose monitoring and flash glucose monitoring in people with Type 1 diabetes and impaired awareness of hypoglycaemia. Diabet Med 2018;35: 483-90. [Medline] [CrossRef]

113. Guilmin-Crépon S, Carel JC, Schroedt J, Sulmont V, Salmon AS, Le Tallec C, et al. Is there an optimal strategy for real-time continuous glucose monitoring in pediatrics? A 12-month French multi-center, prospective, controlled randomized trial (Start-In!). Pediatr Diabetes 2019;20: 304-13. [Medline] [CrossRef]

114. Dicembrini I, Pala L, Caliri M, Minardi S, Cosentino C, Monami M, et al. Combined continuous glucose monitoring and subcutaneous insulin infusion versus self-monitoring of blood glucose with optimized multiple injections in people with type 1 diabetes: A randomized crossover trial. Diabetes Obes Metab 2020;22: 1286-91. [Medline] [CrossRef]

115. Pratley RE, Kanapka LG, Rickels MR, Ahmann A, Aleppo G, Beck R, et al. Wireless Innovation for Seniors With Diabetes Mellitus (WISDM) Study Group. Effect of continuous glucose monitoring on hypoglycemia in older adults with type 1 diabetes: a randomized clinical trial. JAMA 2020;323: 2397-406. [Medline] [CrossRef]

116. Huyett LM, Ly TT, Forlenza GP, Reuschel-DiVirgilio S, Messer LH, Wadwa RP, et al. Outpatient closed-loop control with unannounced moderate exercise in adolescents using zone model predictive control. Diabetes Technol Ther 2017;19: 331-9. [Medline] [CrossRef] 